Research Article

\title{
Cytotoxic Constituents of the Bark of Hypericum roeperianum towards Multidrug-Resistant Cancer Cells
}

\author{
Michel-Gael F. Guefack, ${ }^{1}$ Francois Damen, ${ }^{2}$ Armelle T. Mbaveng $\mathbb{D}^{1}{ }^{1}$ \\ Simplice Beaudelaire Tankeo, ${ }^{1}$ Gabin T. M. Bitchagno, ${ }^{2}$ İlhami Çelik, ${ }^{3}$ \\ James D. Simo Mpetga, ${ }^{2}$ and Victor Kuete $\mathbb{D}^{1}$ \\ ${ }^{1}$ Department of Biochemistry, Faculty of Science, University of Dschang, P.O. Box 67, Dschang, Cameroon \\ ${ }^{2}$ Department of Chemistry, Faculty of Science, University of Dschang, P.O. Box 67, Dschang, Cameroon \\ ${ }^{3}$ Department of Chemistry, Faculty of Science, Eskisehir Technical University, Eskisehir 26470, Turkey
}

Correspondence should be addressed to Victor Kuete; kuetevictor@yahoo.fr

Received 16 April 2020; Revised 29 July 2020; Accepted 4 August 2020; Published 25 September 2020

Guest Editor: Stephen Amoo

Copyright ( $\odot 2020$ Michel-Gael F. Guefack et al. This is an open access article distributed under the Creative Commons Attribution License, which permits unrestricted use, distribution, and reproduction in any medium, provided the original work is properly cited.

\begin{abstract}
The global cancer burden remains a serious concern with the alarming incidence of one in eight men and one in eleven women dying in developing countries. This situation is aggravated by the multidrug resistance (MDR) of cancer cells that hampers chemotherapy. In this study, the cytotoxicity of the methanol extract (HRB), fractions (HRBa, HRBb, and HRBa1-5), and compounds from the bark of Hypericum roeperianum (HRB) was evaluated towards a panel of 9 cancer cell lines. The mode of action of the HRB and trichadonic acid (1) was also studied. Column chromatography was applied to isolate the constituents of HRB. The cytotoxicity of botanicals and phytochemicals was evaluated by the resazurin reduction assay (RRA). Caspase-Glo assay was used to evaluate the activity of caspases, and reactive oxygen species (ROS) $\left(\mathrm{H}_{2} \mathrm{DCFH}-\mathrm{DA}\right)$ were assessed by flow cytometry. Phytochemicals isolated from HRB were trichadonic acid (1), fridelan-3-one (2), 2-hydroxy-5-methoxyxanthone (3), norathyriol (4), 1,3,5,6-tetrahydroxyxanthone (5), betulinic acid (6), $3^{\prime}$-hydroxymethyl-2'-(4" $2^{\prime \prime}$-hydroxy- $3^{\prime \prime}, 5^{\prime \prime}$-dime-

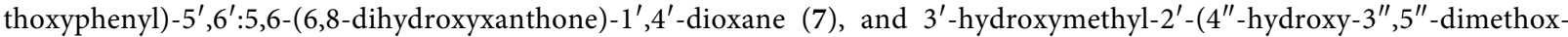
yphenyl)-5',6':5,6-(xanthone)-1 $1^{\prime}, 4^{\prime}$-dioxane (8). Botanicals HRB, HRBa, HRBa2-4, HRBb, and doxorubicin displayed cytotoxic effects towards the 9 tested cancer cell lines. The recorded $\mathrm{IC}_{50}$ values ranged from $11.43 \mu \mathrm{g} / \mathrm{mL}$ (against the P-glycoprotein (gp)-overexpressing CEM/ADR5000 leukemia cells) to $26.75 \mu \mathrm{g} / \mathrm{mL}$ (against HCT116 (p53 ${ }^{+/+}$) colon adenocarcinoma cells) for the crude extract HRB. Compounds 1, 5, and doxorubicin displayed cytotoxic effects towards the 9 tested cancer cell lines with $\mathrm{IC}_{50}$ values varying from $14.44 \mu \mathrm{M}$ (against CCRF-CEM leukemia cells) to $44.20 \mu \mathrm{M}$ (against the resistant HCT116 (p53 ${ }^{-/-}$) cells) for 1 and from $38.46 \mu \mathrm{M}$ (against CEM/ADR5000 cells) to $112.27 \mu \mathrm{M}$ (against the resistant HCT116 (p53 $\left.{ }^{-1-}\right)$ cells) for 5. HRB and compound 1 induced apoptosis in CCRF-CEM cells. The apoptotic process was mediated by enhanced ROS production for HRB or via caspases activation and enhanced ROS production for compound $\mathbf{1}$. This study demonstrated that Hypericum roeperianum is a potential source of cytotoxic phytochemicals such as trichadonic acid and could be further exploited in cancer chemotherapy.
\end{abstract}

\section{Introduction}

Cancer continues to be a global threat, appearing as the second leading cause of death globally, with estimated 9.6 million deaths representing one in six deaths and with an estimated five-year prevalence of 43.8 million people [1]. Multidrug resistance (MDR) of cancer cells is a serious concern in chemotherapy. It is responsible for many therapeutic failures and high burdens globally, in patients suffering from cancer [2,3]. Any modern protocol for new cytotoxic drug discovery today should integrate the ability of neoplastic cells to rapidly develop resistant phenotypes. Thus, resistant cell lines should be integrated into the cell panel used for the discovery of more efficient 
substances. The present work has taken this into account and involves several models of MDR cancer cell lines such as the colon adenocarcinoma with p53 knockout phenotype, the leukemia cells with ATP-binding cassette $(\mathrm{ABC})$-transporter-overexpressing MDR-mediating-Pglycoprotein (P-gp; ABCB1/MDR1), the breast cancer bearing resistance protein (ABCG2/BCRP), and the transfectant glioblastoma multiforme harboring a mutation-activated EGFR gene ( $\triangle \mathrm{EGFR})$. The effectiveness of natural products in the fight against cancer has been largely demonstrated [4]. Some clinically established cytotoxic drugs such as camptothecin, paclitaxel, vinblastine, or vincristine are naturally occurring compounds [4-6]. In addition, numerous botanicals and phytochemicals derived from African medicinal plants have been found active against MDR cancer cell lines $[7,8]$. Some of such prominent phytochemicals include terpenoids: salvimulticanol and candesalvone B methyl ester [9], epunctanone [10], and ardisiacrispin B [11], phenolics: 2-acetyl-7-methoxynaphtho [2,3-b]furan-4,9quinone [12], 6 $\alpha$-hydroxyphaseollidin [13], licoagrochalcone A [14], 7-dihydroxy-4'-methoxy-6,8diprenylisoflavone, and 7,7"-di-O-methylchamaejasmin [15], and alkaloids: 1,3-dimethoxy-10-methylacridone [16], isotetrandrine [17], and ungeremine [18]. However, more hit compounds should be identified to increase our arsenal of cytotoxic compounds and to secure better the chances of later obtaining new clinically usable molecules. The present study was, therefore, designed to assess the cytotoxicity of botanicals and phytochemicals from the bark of Hypericum roeperianum Schimp. p. ex A. Rich (Guttiferae). The modes of action of compound $\mathbf{1}$, such as its effects on cell cycle distribution and induction of apoptosis, on caspases activation, and on the production of reactive oxygen species (ROS), were also investigated. Hypericum roeperianum is a shrub or small tree growing in the tropical part of central, eastern, and southern tropical Africa, locally used alone or in association with various plants in the treatment of female sterility [19], as antiabortifacients [20] and as antifungal remedies [21]. Previous phytochemical investigations of this plant led to the isolation of a polyketide, 4-methoxy-3-(2-methylbut3 -en-2-yl)-6-phenyl-2H-pyran-2-one, xanthones: 1,5 dihydroxy-6-methoxyxanthone, 2-hydroxy-5-methoxyxanthone and 1,4,6,7-tetrahydroxyxanthone, and the xanthonolignoids: $\quad 8,10$-dihydroxy-3-(4hydroxy-3,5dimethoxyphenyl-2-(hydroxymethyl)-2, 3-dihydro-[1, 4] dioxino[2,3-c]xanthen-7-one and 8-hydroxy-10methoxy-3-(4-hydroxy-3,5-dimethoxyphenyl-2-(hydroxymethyl)-2,3-dihydro-[1,4] dioxino[2,3-c] xanthen-7-one from the bark [22] and 10 other xanthones from the roots, namely, 5-O-methyl-2-deprenylrheediaxanthone $\mathrm{B}, 5-\mathrm{O}$ methylisojacareubin, 5-O-demethylpaxanthonin, roeperanone, 2-hydroxyxanthone, 5-hydroxy-2-methoxyxanthone, 1,5-dihydroxy-2-methoxyxanthone, 2-deprenyl rheediaxanthone $\mathrm{B}$, isojacareubin, and calycinoxanthone $\mathrm{D}$ [23]. The cytotoxicity of botanicals from the bark of Hypericum roeperianum is being reported for the first time.

\section{Material and Methods}

2.1. Chemicals. Doxorubicin ( $98.0 \%$ purity) from SigmaAldrich (Munich, Germany) was obtained from the Johannes Gutenberg University Medical Center (Mainz, Germany). Geneticin $>98 \%$ (used at $800 \mathrm{ng} / \mathrm{mL}$ and $400 \mu \mathrm{g} / \mathrm{mL}$ ) in culture media to maintain the features of MDA-MB-231$B C R P$, U87MG. $\triangle E G F R$, and HCT116 $\left(p 53^{-} I^{-}\right)$, respectively, was obtained from Sigma-Aldrich and stored at $72.18 \mathrm{mM}$. Hydrogen peroxide $\left(\mathrm{H}_{2} \mathrm{O}_{2}\right)$ and valinomycin (at $1 \mathrm{mg} / \mathrm{mL}$ ) were provided by Sigma-Aldrich (Taufkirchen, Germany).

2.2. Plant Material and Extraction. The bark of Hypericum roeperianum Schimp. p. ex A. Rich (Guttiferae) was collected in Bangang Wabane (South West Region of Cameroon) in October 2018. No permission was necessary for sample's collection. The identification of the plant was carried out by Dr. Tchiengue Barthelemy at the Cameroon National Herbarium (Yaoundé) where a voucher specimen was deposited under the number 24584/SRF/Cam. Dried barks of the plant $(3.0 \mathrm{~kg})$ were powdered and extracted with methanol $(\mathrm{MeOH}$; $3 \times 15 \mathrm{~L}$ ) for $72 \mathrm{~h}$ at room temperature to afford a crude extract (HRB; $150.0 \mathrm{~g}$ ) after filtration with Whatman paper no. 1 and evaporation in vacuum, under reduced pressure. A portion of the resulting extract $(140.0 \mathrm{~g})$ was, then, exhausted in ethyl acetate to yield $65.0 \mathrm{~g}$ of the ethyl acetate extract (EtOAc) (HRBa) and the residue ( $\mathrm{HRBb} ; 75 \mathrm{~g})$.

2.3. Fractionation and Purification of the Bark Extract of Hypericum roeperianum. Part of the ethyl acetate extract (EtOAc; 60.0 g) was submitted to silica gel flash chromatography using hexane-EtOAc and, then, EtOAc-MeOH mixtures of increasing polarities. Eighty fractions (frs) of $500 \mathrm{~mL}$ each were collected as follows: hexane 100\% (sub-frs 1-3), hexane-EtOAc $90: 10$ (sub-frs 4-12), hexane-EtOAc 80 : 20 (sub-frs 13-18), hexane-EtOAc 70:30 (sub-frs 19-22), hexane-EtOAc $60: 40$ (sub-frs 23-27), hexane-EtOAc 50:50 (sub-frs 28-37), hexane-EtOAc 30:70(sub-frs 38-43), AcOEt 100\% (sub-frs 44-52), EtOAc-MeOH 95:5 (sub-frs 53-57), EtOAc-MeOH 90:10 (sub-frs 58-62), EtOAc-MeOH 80:20 (sub-frs 63-69), and $\mathrm{MeOH} \mathrm{100 \%} \mathrm{(sub-frs} \mathrm{70-80).} \mathrm{Based} \mathrm{on}$ their analytical thin-layer chromatography (TLC) profiles, these fractions were pooled into five fractions (frs) as follows: HRBa1 (Sub-frs 1-15, 8.0 g), HRBa2 (Sub-frs 16-25, 15.0 g), HRBa3 (Sub-frs 28-38, 9.5 g), HRBa4 (Sub-frs 39-68, 12.5 g), and HRBa5 (Sub-frs 69-80, 13.0 g).

Dry fraction HRBa2 $(15.0 \mathrm{~g})$ was dissolved in methanol affording a nonsoluble powder which was, then, filtered to give compound $\mathbf{1}(15 \mathrm{mg})$. The filtrate was subjected to silica gel column chromatography using hexane-AcOEt mixtures of increasing polarities as elution solvents. Sixty-five sub-frs of $150 \mathrm{~mL}$ each were collected as follows: Hex $100 \%(1-3)$, Hex-AcOEt 90:10 (Sub-frs 4-9), Hex-AcOEt 80 : 20 (Sub-frs 10-15), Hex-AcOEt $70: 30$ (Sub-frs 16-19), Hex-AcOEt 60 : 40 (Sub-frs 20-35), Hex-AcOEt 50:50 (Sub-frs 36-42), Hex-AcOEt 40:60 (Sub-frs 43-50), AcOEt 100\% (Sub-frs 51-55), AcOEt-MeOH 90:10 (Sub-frs 56-60), and $\mathrm{MeOH}$ $100 \%$ (Sub-frs 61-65). Sub-frs 6-9 yielded compound 2 
$(15.0 \mathrm{mg})$ as a white powder. Sub-frs EC23-29 yielded compound $3(12.0 \mathrm{mg})$ as a yellow powder.

HRBa3 (9.5 g) was subjected to silica gel column chromatography using Hex-AcOEt mixtures of increasing polarities as elution solvents. Seventy-five sub-frs of $150 \mathrm{~mL}$ each were collected as follows: hexane $100 \%$ (sub-frs 1-4), Hex-AcOEt $90: 10$ (sub-frs 5-9), Hex-AcOEt $80: 20$ (sub-frs 9-16), Hex-AcOEt $70: 30$ (sub-frs 17-23), Hex-AcOEt 60 : 40 (sub-frs 24-35), Hex-AcOEt $50: 50$ (sub-frs 36-42), HexAcOEt 40 : 60 (sub-frs 43-47), AcOEt 100\% (sub-frs 48-57), AcOEt-MeOH $90: 10$ (sub-frs 58-63), AcOEt-MeOH $80: 20$ (sub-frs 64-70), and $\mathrm{MeOH} 100 \%$ (sub-frs 71-75). Sub-frs 22-25 yielded compound $4(18.0 \mathrm{mg})$ as a green-yellowish powder. Sub-frs 29-35 yielded compound 5 as a yellow powder $(15.0 \mathrm{mg})$.

HRBa4 (12.5 g) was subjected to silica gel column chromatography using $\mathrm{CH}_{2} \mathrm{Cl}_{2}-\mathrm{MeOH}$ mixtures of increasing polarities as elution solvents. Fifty sub-frs of $150 \mathrm{~mL}$ each were collected as follows: $\mathrm{CH}_{2} \mathrm{Cl}_{2} 100 \%$ (sub-frs 1-4), $\mathrm{CH}_{2} \mathrm{Cl}_{2}-\mathrm{MeOH} 95: 5$ (sub-frs 5-13), $\mathrm{CH}_{2} \mathrm{Cl}_{2}-\mathrm{MeOH} 90: 10$ (sub-frs 14-25), $\mathrm{CH}_{2} \mathrm{Cl}_{2}-\mathrm{MeOH} 85: 15$ (sub-frs 26-35), $\mathrm{CH}_{2} \mathrm{Cl}_{2}-\mathrm{MeOH} 80: 20$ (sub-frs 36-42), and $\mathrm{MeOH} 100 \%$ (subfrs 43-50). Sub-frs 6-11 yielded compound 6 (40.0 mg) as a white powder. Sub-frs 13-15 yielded compound 7 $(12.0 \mathrm{mg})$ as a yellow powder. Sub-frs 19-23 yielded compound $8(14.0 \mathrm{mg})$ as a yellow powder.

2.4. Cell Cultures. Cell lines used in this work included drugsensitive and drug-resistant phenotypes of earlier reported origin. They were all provided by Prof. Dr. Thomas Efferth from his cell lines collection; they have being used in cytotoxicity screening by our team for a decade [12-21]. These include two hematological cancer cell lines, namely, the drug-sensitive CCRF-CEM leukemia cell line and its multidrug-resistant P-gp-over-expressing subline CEM/ ADR5000 cells [24-26] and nine carcinoma cell lines, namely, U87.MG glioblastoma cell line and its EGFRtransfected U87.MG $\triangle E G F R$ subline, HCT116 $\left(p 53^{+/+}\right)$colon cancer cell line and its knockout clone HCT116 $\left(p 53^{-} /^{-}\right)$, and MDA-MB-231-pcDNA3 breast cancer cell line and its $B C R P$-transfected multidrug-resistant MDA-MB-231-BCRP clone 23 cell line [27], as well as the normal AML12 hepatocytes, used to compare with HepG2 liver cancer cells [13].

2.5. Resazurin Reduction Assay (RRA) for Cell Growth Evaluation. The RRA was applied to evaluate the cytotoxicity of botanicals, the isolated phytochemicals (1-5, 7, and 8), and doxorubicin on the cell growth as reported earlier $[18,28]$. Cells treated with various samples at different concentrations were incubated for $72 \mathrm{~h}$ in humidified $5 \%$ $\mathrm{CO}_{2}$ atmosphere at $37^{\circ} \mathrm{C}$. Cells were further coloured with resazurin and incubated for $1-2 \mathrm{~h}$; the fluorescence was further measured with an Infinite M2000 Pro ${ }^{\text {тм }}$ plate reader (Tecan, Crailsheim, Germany) at $544 \mathrm{~nm}$ as the excitation wavelength and $590 \mathrm{~nm}$ as the emission wavelength. The $\mathrm{IC}_{50}$ values represented the concentrations of the sample required to inhibit $50 \%$ of cell proliferation and were calculated from a calibration curve by linear regression using Microsoft Excel 2007 [29].

2.6. Flow Cytometric Evaluation of Cell Cycle Distribution and Apoptotic Cells. Various concentrations of botanical $\mathrm{HRB}$, phytochemical 1, and doxorubicin or DMSO (solvent control) were used to treat CCRF-CEM cells $\left(1 \times 10^{6}\right.$ cells). Cells were further incubated for $24 \mathrm{~h}$ in humidified $5 \% \mathrm{CO}_{2}$ atmosphere at $37^{\circ} \mathrm{C}$ and analyzed using a BD Accury C6 Flow Cytometer (BD Biosciences, Heidelberg, Germany) by measuring the propidium iodide fluorescence of individual nucleus, as described earlier [10, 11]. Experiments were conducted thrice independently with three parallel measurements.

\subsection{Assessment of Apoptosis by Annexin V/PI Staining.} The CCRF-CEM cells $\left(1 \times 10^{6} ; 1 \mathrm{ml}\right)$ were also treated with $\mathrm{HRB}$, compound 1 and doxorubicin for $24 \mathrm{~h}$ (in humidified 5\% $\mathrm{CO}_{2}$ atmosphere at $37^{\circ} \mathrm{C}$ ), and apoptosis was further assessed by flow cytometry using the flouresceinisothiocynate- (FITC-) conjugated annexin V/PI assay kit (eBioscience Annexin V; Invitogen, San Diego, USA), as previously published [10, 11]. Briefly, treated cells were centrifuged at $1200 \mathrm{rpm}$ for $5 \mathrm{~min}$, then washed twice with ice-cold PBS, resuspended in $500 \mu \mathrm{l}$ binding buffer, and stained with $5 \mu \mathrm{l}$ FITC-conjugated annexin $\mathrm{V}(10 \mathrm{mg} / \mathrm{mL})$ and $10 \mu \mathrm{l}$ PI $(50 \mathrm{mg} / \mathrm{ml})$. After $15 \mathrm{~min}$ incubation at room temperature (RT) in the dark, cells were analyzed using a BD Accury C6 Flow Cytometer (BD Biosciences). Cells stained with only annexin $\mathrm{V}$ were evaluated as being in early apoptosis. Cells stained with both annexin V and propidium iodide were evaluated as being in late apoptosis or in a necrotic stage.

2.8. Evaluation of Caspases Activities Using Caspase-Glo 3/7, Caspase-Glo 8, and Caspase-Glo 9. Different concentrations of HRB and compound $\mathbf{1}$ were used to treat CCRF-CEM cells for $6 \mathrm{~h}$. The activities of caspases were determined using Caspase-Glo 3/7, Caspase-Glo 8, and Caspase-Glo 9 Assay kits (Promega, Mannheim, Germany) by measuring the luminescence using an Infinite M2000 ProTM plate reader (Tecan), as reported previously [13].

2.9. Evaluation of Reactive Oxygen Species (ROS) Production. Various concentrations of HRB and triterpenoid 1 were used to treat CCRF-CEM cells $\left(1 \times 10^{6}\right.$ cells); DMSO (solvent control); or hydrogen peroxide $\left(\mathrm{H}_{2} \mathrm{O}_{2}\right.$; positive control). After $24 \mathrm{~h}$ incubation in humidified $5 \% \mathrm{CO}_{2}$ atmosphere at $37^{\circ} \mathrm{C}$, the production of ROS was evaluated using $2^{\prime}, 7^{\prime}$ dichlorodihydrofluorescein diacetate ( $\left.\mathrm{H}_{2} \mathrm{DCFH}-\mathrm{DA}\right)$ (Sigma-Aldrich) staining, as described earlier [30-32].

2.10. Statistics. Statistical analyses were performed with Graph pad prism 5 software. Representative data from three independent experiments are shown as mean value \pm S.E.M. One-way Analysis Variance (ANOVA) followed by post hoc Tukey's test was used to determine the significance of the 
difference between mean values relative to the control. The $p$ value was calculated to determine significant differences ( $p$ value $<0.05)$.

\section{Results}

3.1. Phytochemistry. The chemical structures of the isolated phytochemicals were determined by exploiting the physical, mass spectra, and NMR data, followed by direct comparison of these data with those of similar reported compounds in the literature. Compounds were identified as trichadonic acid $\mathrm{C}_{30} \mathrm{H}_{48} \mathrm{O}_{3}$ (1; white amorphous powder; $m / z$ 456) [33], fridelan-3-one $\mathrm{C}_{30} \mathrm{H}_{50} \mathrm{O}$ (2; white powder; m.p. $258^{\circ} \mathrm{C}$; $\mathrm{m} / z 426$ ) [33], 2-hydroxy-5-methoxyxanthone $\mathrm{C}_{14} \mathrm{H}_{10} \mathrm{O}_{4}$ (3; yellow amorphous powder; $m / z$ 242) [34], 1,3,6,7-tetrahydroxyxanthone or norathyriol $\mathrm{C}_{13} \mathrm{H}_{8} \mathrm{O}_{6}$ (4; green-yellowish powder; m.p. $271^{\circ} \mathrm{C} ; m / z$ 260) [35], 1,3,5,6-tetrahydroxyxanthone $\mathrm{C}_{13} \mathrm{H}_{8} \mathrm{O}_{6}$ (5; yellow powder; m.p. $136^{\circ} \mathrm{C} ; \mathrm{m} / z$ 260) [36], betulenic acid $\mathrm{C}_{30} \mathrm{H}_{48} \mathrm{O}_{3}$ (6; white powder; m.p. $318^{\circ} \mathrm{C} ; \mathrm{m} / z$ 456) [33], 3'-hydroxymethyl- $2^{\prime}-\left(4^{\prime \prime}\right.$-hydroxy- $3^{\prime \prime}, 5^{\prime \prime}$-dimethoxyphenyl)- $5^{\prime}, 6^{\prime}: 5,6$-(6,8-dihydroxyxanthone)- $1^{\prime}, 4^{\prime}$-dioxane $\mathrm{C}_{24} \mathrm{H}_{20} \mathrm{O}_{8}$ (7; yellow powder; m.p. $264^{\circ} \mathrm{C} ; \mathrm{m} / z$ 436) [37, 38], and $3^{\prime}$-hydroxymethyl- $2^{\prime}-\left(4^{\prime \prime}\right.$-hydroxy- $3^{\prime \prime}, 5^{\prime \prime}$ dimethoxyphenyl)- $5^{\prime}, 6^{\prime}: 5,6$-(xanthone)-1 $1^{\prime}, 4^{\prime}$-dioxane $\mathrm{C}_{2420}$ $\mathrm{O}_{10}$ (8; yellow amorphous powder; $m / z$ 468) [37] (Figure 1). The 1D NMR spectra of these compounds are provided as Supplementary Materials.

3.2. Cytotoxicity of Phytochemicals and Doxorubicin. The cytotoxicity of crude extracts, fractions, and phytochemicals $\mathbf{1 - 5}, 7, \mathbf{8}$, and doxorubicin was investigated using RRA towards 9 cancer cell lines and normal AML12 hepatocytes (Tables 1 and 2). The degree of resistance (D.R.) of the tested samples was determined as the ratio of the $\mathrm{IC}_{50}$ value of the resistant cell line divided by that of the corresponding parental sensitive cell line (Tables 1 and 2). Collateral sensitivity or hypersensitivity was deduced if the D.R. was below 1 while normal sensitivity was defined as a D.R. of 1 or around 1; cross resistance was considered as a D.R. above 1. The selectivity index (S.I.) was also calculated as the ratio of the $\mathrm{IC}_{50}$ value in normal AML12 hepatocytes by the corresponding values in HepG2 hepatocarcinoma cells (Tables 1 and 2).

The obtained $\mathrm{IC}_{50}$ values ranged from $11.43 \mu \mathrm{g} / \mathrm{mL}$ (against the P-gp-overexpressing CEM/ADR5000 leukemia cells) to $26.75 \mu \mathrm{g} / \mathrm{mL}$ (against HCT116 ( $553^{+/+}$) colon adenocarcinoma cells) for the crude extract $\mathrm{HRB}$, from $15.65 \mu \mathrm{g} / \mathrm{mL}$ (against CEM/ADR5000 leukemia cells) to $41.17 \mu \mathrm{g} / \mathrm{mL}$ (against HCT116 $\left(\mathrm{p} 53^{+/+}\right.$) cells) for HRBa, from $13.92 \mu \mathrm{g} / \mathrm{mL}$ (against U87MG. $\triangle \mathrm{EGFR}$ glioblastoma cells) to $33.44 \mu \mathrm{g} / \mathrm{mL}$ (against HCT116 (p53 ${ }^{+/+}$) cells) for $\mathrm{HRBa} 2$, from $16.13 \mu \mathrm{g} / \mathrm{mL}$ (against U87MG glioblastoma cells) to $33.63 \mu \mathrm{g} / \mathrm{mL}$ (against HCT116 (p53 ${ }^{-9-}$ ) cells) for HRBa3, from $10.52 \mu \mathrm{g} / \mathrm{mL}$ (against U87MG. $\triangle \mathrm{EGFR}$ cells) to $28.43 \mu \mathrm{g} / \mathrm{mL}$ (against HCT116 (p53 $3^{+/+}$) cells) for HRBa4, and from $28.30 \mu \mathrm{g} / \mathrm{mL}$ (against U87MG. $\mathrm{EEGFR}$ cells) to $69.48 \mu \mathrm{g} / \mathrm{mL}$ (against HepG2 cells) for HRBb (Table 1). Fractions HRBal and HRBa5 had selective activities (Table 1).
Triterpenoid 1, xanthone 5, and doxorubicin displayed cytotoxic effects towards the 9 tested cancer cell lines with $\mathrm{IC}_{50}$ values ranging from $14.44 \mu \mathrm{M}$ (against CCRF-CEM cells) to $44.20 \mu \mathrm{M}$ (against the resistant HCT116 (p53 ${ }^{-/-}$) cells) for 1 , from $38.46 \mu \mathrm{M}$ (against CEM/ADR5000 cells) to 112.27 $\mu \mathrm{M}$ (against HCT116 (p53 ${ }^{-/-}$) cells) for 5, and from $0.02 \mu \mathrm{M}$ (against CCRF-CEM cells) to $122.96 \mu \mathrm{M}$ (against CEM/ADR5000 cells) for doxorubicin (Table 2). Xanthones $\mathbf{3}$ and $\mathbf{4}$, as well as xantholignans $\mathbf{7}$ and $\mathbf{8}$, had selective cytotoxic effects (Tables 2).

Collateral sensitivity (D.R. below 1) of CEM/ADR5000 cells, BCRP-expressing MDA-MB-231 cells, and HCT116 $\left(\mathrm{p} 53^{-/-}\right.$) cells to the mother botanical, HRB compared to their sensitive counterparts CCRF-CEM cells, MDA-MB231 cells, and HCT116 ( $\mathrm{p} 53^{+/+}$) cells, respectively, was observed. Hypersensitivity of all resistant cell lines to fraction $\mathrm{HRBa} 4$ and $\mathrm{HRBb}$ compared to their sensitive parental cell lines was also recorded (Table 1). Collateral sensitivity of BCRP-expressing MDA-MB-231 cells and U87MG.AEGFR cells to phytochemicals $\mathbf{1}, \mathbf{3 - 5}$, and 8 compared to their sensitive counterparts MDA-MB-231 cells and U87MG cells, respectively, was also observed (Table 2). Concerning the most active compound $\mathbf{1}$, a little cross resistance of HCT116 ( $553^{-/-}$) cells compared to their sensitive counterparts HCT116 (p53 $\left.{ }^{+/+}\right)$was observed with a D.R. of 2.55; however, this value was lower than that obtained with doxorubicin (D.R. of 3.73) (Table 2). Apart against HRBb, the S.I. of all samples was above 2 in HepG2 as compared with normal AML12 hepatocytes (Table 1). Compounds 1, 3, 5, 8, and doxorubicin had an S.I. above 2 in HepG2 as compared with normal AML12 hepatocytes (Table 1). Regarding the recorded $\mathrm{IC}_{50}$ values, trichadonic acid (1) had the best activity and was consequently selected, together with the crude extract, HRB, for further mechanistic studies.

3.3. Cell Cycle Distribution and Apoptosis. The crude extract (HRB) and triterpenoid $\mathbf{1}$, as well as doxorubicin, caused dose-dependent alteration of CCRF-CEM cells' cycle distribution after $24 \mathrm{~h}$ treatment (Figure 2). Figure 2 shows that HRB and trichadonic acid (1) induced increase of cells in the sub-G0/G1 phase, varying from $1.68 \%$ $\left(1 / 4 \times \mathrm{IC}_{50}\right)$ to $24.30 \%\left(2 \times \mathrm{IC}_{50}\right)$ for $\mathrm{HRB}$ and from $1.86 \%$ $\left(1 / 4 \times \mathrm{IC}_{50}\right)$ to $17.40 \%\left(2 \times \mathrm{IC}_{50}\right)$ for compound 1 , while doxorubicin induced increase in the range of $3.28 \%$ (1/ $\left.4 \times \mathrm{IC}_{50}\right)$ to $12.05 \%\left(2 \times \mathrm{IC}_{50}\right)$. This suggests that $\mathrm{HRB}$ and compound $\mathbf{1}$ induced apoptosis in CCRF-CEM cells. Increase of cells in the Go/G1 phase also suggests that both $\mathrm{HRB}$ and trichadonic acid caused cycle arrest in this phase; meanwhile, doxorubicin induced $S$ and $G 2 / M$ phase arrest (Figure 2). A concentration-dependent induction of apoptosis by HRB and compound 1, as well as doxorubicin, was further confirmed by annexin V/PI staining (Figure 3 ). At $2 \times \mathrm{IC}_{50}$ for example, $\mathrm{HRB}$ significantly $(p<0.05)$ induced late apoptosis (Q2-UR) while compound 1 significantly $(p<0.05)$ induced early apoptosis with, respectively, $14.6 \%$ annexin $\mathrm{V}(+) / \mathrm{PI}(-)$ and $52.5 \%$ annexin $\mathrm{V}(+) / \mathrm{PI}(+)$ cells (Figure 3 ). 


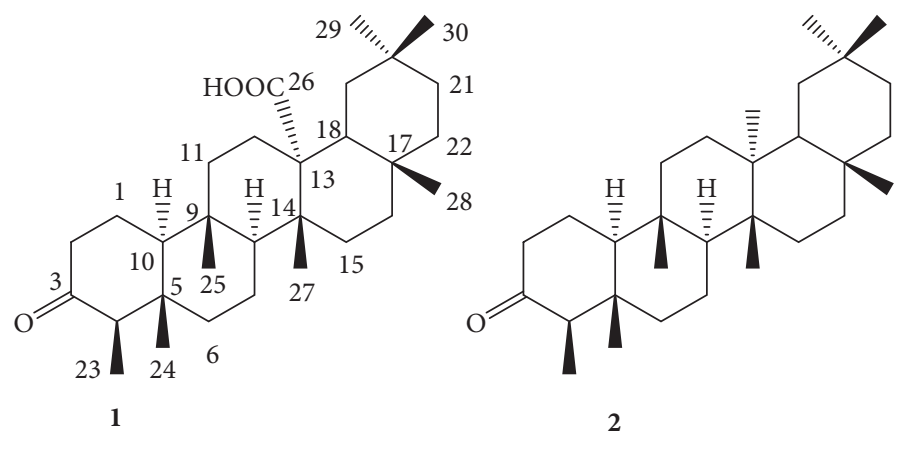<smiles>COc1cccc2c(=O)c3c(C)c(O)ccc3oc12</smiles><smiles>C=C(C)C1CC[C@]2(C(=O)O)CC[C@]3(C)C(CCC4[C@@]5(C)CCC(O)C(C)(C)C5CC[C@]43C)C12</smiles><smiles>CCC1Oc2c(ccc3c(=O)c4c(O)cc(O)cc4oc23)O[C]1c1cc(OC)c(O)c(OC)c1</smiles><smiles>COc1cc(C2Oc3ccc4c(=O)c5ccccc5oc4c3OC2CO)cc(OC)c1O</smiles>

8

FIGURE 1: Chemical structures of phytochemicals isolated from the bark methanol extract of Hypericum roeperianum. 1: Trichadonic acid; 2: fridelan-3-one; 3: 2-hydroxy-5-methoxyxanthone; 4:1,3,6,7-tetrahydroxyxanthone or norathyriol; 5:1,3,5,6-tetrahydroxyxanthone; 6: betulenic acid; and $7: 3^{\prime}$-hydroxymethyl-2'-( $4^{\prime \prime}$-hydroxy- $3^{\prime \prime}, 5^{\prime \prime}$-dimethoxyphenyl)- $5^{\prime}, 6^{\prime}: 5,6$-(6,8-dihydroxyxanthone)- $1^{\prime}, 4^{\prime}$-dioxane; $8: 3^{\prime}$ hydroxymethyl-2' $-\left(4^{\prime \prime}\right.$-hydroxy- $3^{\prime \prime}, 5^{\prime \prime}$-dimethoxyphenyl)-5', $6^{\prime}: 5,6$-(xanthone)-1 $1^{\prime}, 4^{\prime}$-dioxane.

TABLE 1: Recorded $\mathrm{IC}_{50}$ values after $72 \mathrm{~h}$ incubation of drug-sensitive and MDR cancer cells lines with botanicals from the bark of $H y p e r i c u m$ roeperianum.

\begin{tabular}{|c|c|c|c|c|c|c|c|c|}
\hline \multirow{2}{*}{ Cell lines } & \multicolumn{8}{|c|}{ Samples, $\mathrm{IC}_{50}$ values in $\mu \mathrm{g} / \mathrm{mL}$, and degrees of resistance* or selectivity index ${ }^{* *}$} \\
\hline & HRB & $\mathrm{HRBa}$ & HRBa1 & $\mathrm{HRBa} 2$ & $\mathrm{HRBa} 3$ & $\mathrm{HRBa} 4$ & $\mathrm{HRBa} 5$ & $\mathrm{HRBb}$ \\
\hline CCRF-CEM & $13.71 \pm 0.26$ & $15.65 \pm 1.18$ & $46.42 \pm 1.98$ & $17.87 \pm 1.53$ & $16.81 \pm 4.02$ & $16.27 \pm 4.28$ & $57.15 \pm 3.76$ & $48.76 \pm 2.83$ \\
\hline CEM/ADR500 & .88 & $18.56 \pm 1$ & $>80$ & $20.18 \pm 1.76$ & $23.03 \pm 1$ & $13.55 \pm 0.44$ & & 31.55 \\
\hline Degree of resistance* & 0.84 & 1.19 & $>1.72$ & 1.13 & 1.37 & 0.83 & $>1$ & 0.65 \\
\hline MDA-MB-231-pcDNA & $19.87 \pm 1.77$ & $23.12 \pm 1.65$ & $72.23 \pm 4.54$ & $20.42 \pm 1.71$ & 28.32 & $18.13=$ & 68.91 & $48.12 \pm 1.99$ \\
\hline MDA-MB- & $18.22 \pm 0.81$ & $26.42 \pm 3.01$ & $63.16 \pm 3.30$ & $19.89 \pm 0.62$ & $24.41 \pm 1.77$ & $17.66 \pm 1.11$ & $74.32 \pm 3.92$ & $37.23 \pm 4.51$ \\
\hline Degree of $r$ & 0.92 & 1.14 & 0.87 & 0.97 & 0.86 & 0.97 & 1.08 & 0.77 \\
\hline HCT116 $\left(p 53^{+/+}\right)$ & $26.75 \pm 1.23$ & $34.52 \pm 1.74$ & $59.10 \pm 3.06$ & $33.44 \pm 3.62$ & $30.76 \pm 1.61$ & $28.43 \pm 3.01$ & $>80$ & $31.19 \pm 1.26$ \\
\hline HCT11 & $17.44 \pm 2.01$ & $41.17 \pm 3.14$ & $>80$ & $24.58 \pm$ & 33.63 & $28.09 \pm 1.75$ & $>80$ & 29.52 \\
\hline Degree of resistance & 0.65 & 1.19 & & 0.74 & 1.09 & 0.99 & & 0.95 \\
\hline U87MG & $2.42 \pm 0.66$ & $18.03 \pm 1.77$ & $47.84 \pm 4.36$ & $18.01 \pm 1.19$ & $16.13 \pm 2.04$ & $18.44 \pm 2.11$ & $47.89 \pm 2.24$ & $46.55 \pm 2.43$ \\
\hline $\mathrm{U} 87 \mathrm{M}$ & $14.36 \pm 1.48$ & $20.12 \pm 0.81$ & $59.60 \pm 5.12$ & $13.92 \pm 2.07$ & $18.72 \pm 1.45$ & $15.52 \pm 0.88$ & $55.20 \pm 4.79$ & $28.30 \pm 1.11$ \\
\hline Degree of resistance & 1.16 & 1.12 & 1.25 & 0.77 & 1.16 & 0.84 & 1.15 & 0.60 \\
\hline HepG2 & $17.45 \pm 2.05$ & $29.17 \pm 1.30$ & $>80$ & $18.75 \pm 1.41$ & $25.88 \pm 1.56$ & $14.95 \pm 1.34$ & $>80$ & $69.48 \pm 2.93$ \\
\hline AML12 & $42.09 \pm 1.17$ & $>80$ & $>80$ & $61.34 \pm 3.39$ & $56.12 \pm 2.67$ & $65.17 \pm 4.31$ & $>80$ & $>80$ \\
\hline Selectivity index ${ }^{* *}$ & 2.41 & $>2.74$ & & 3.27 & 2.17 & 4.56 & & 1.15 \\
\hline
\end{tabular}

$\left({ }^{*}\right)$ : the degree of resistance was determined as the ratio of the $\mathrm{IC}_{50}$ value in the resistant divided by the $\mathrm{IC}_{50}$ in the sensitive cell line; CEM/ADR5000, MDAMB-231-BCRP, HCT116 $\left(p 53^{-} /^{-}\right)$, and U87MG. $\triangle E G F R$ were used as the corresponding resistant counterpart for CCRF-CEM, MDA-MB-231- $p c D N A$, HCT116 $\left(p 53^{+/+}\right)$, and U87MG, respectively; $\left(^{* *}\right)$ : the selectivity index was determined as the ratio of the $\mathrm{IC}_{50}$ value in the normal AML12 hepatocytes divided by the $\mathrm{IC}_{50}$ in HepG2 hepatocarcinoma cells; in bold: significant cytotoxic effect [7,39, 40]; nd: not determined; HRB: crude methanol extract from the bark of Hypericum roeperianum, HRBa: portion obtained by exhaustion of HRB with ethyl acetate; HRBa1-5: fractions from HRBa; HRBb: residual fraction obtained after exhaustion of HRB with ethyl acetate. The data for doxorubicin used as positive control in similar experimental conditions are shown in Table 2. 
TABLE 2: Recorded $\mathrm{IC}_{50}$ values following RRA for phytochemicals isolated from the bark of Hypericum roeperianum and reference drug, doxorubicin, towards drug-sensitive, MDR cancer cells lines and hepatocytes after $72 \mathrm{~h}$ incubation.

\begin{tabular}{|c|c|c|c|c|c|c|c|}
\hline \multirow{2}{*}{ Cell lines } & \multicolumn{7}{|c|}{ Samples, $\mathrm{IC}_{50}$ values in $\mu \mathrm{M}$, and degrees of resistance* or selectivity index** } \\
\hline & 1 & 3 & 4 & 5 & 7 & 8 & Doxorubicin \\
\hline CCRF-CEM & $14.44 \pm 0.53$ & $16.80 \pm 0.96$ & $19.94 \pm 2.12$ & $38.58 \pm 2.11$ & $23.28 \pm 1.46$ & $16.31 \pm 2.12$ & $0.02 \pm 0.00$ \\
\hline CEM/ADR5000 & $18.27 \pm 1.56$ & $52.95 \pm 3.08$ & $23.21 \pm 1.66$ & $38.46 \pm 4.07$ & $54.04 \pm 4.38$ & $43.47 \pm 2.97$ & $122.96 \pm 10.94$ \\
\hline Degree of resistance* & 1.26 & 3.15 & 1.16 & 1.00 & 2.32 & 2.66 & $6,683.00$ \\
\hline MDA-MB-231-pcDNA & $16.47 \pm 0.74$ & $43.80 \pm 3.47$ & $>153.85$ & $75.15 \pm 4.88$ & $20.73 \pm 1.32$ & $36.89 \pm 2.73$ & $0.13 \pm 0.01$ \\
\hline MDA-MB-231- $B C R P$ & $14.95 \pm 1.17$ & $33.60 \pm 1.99$ & $20.38 \pm 1.17$ & $62.94 \pm 5.32$ & $22.16 \pm 2.88$ & $30.50 \pm 1.88$ & $0.79 \pm 0.08$ \\
\hline Degree of resistance & 0.91 & 0.77 & $<0.13$ & 0.84 & 1.07 & 0.83 & 6.14 \\
\hline HCT116 $\left(p 53^{+/+}\right)$ & $17.36 \pm 1.84$ & $46.67 \pm 3.38$ & $40.17 \pm 3.09$ & $75.48 \pm 6.10$ & $>91.74$ & $37.79 \pm 2.92$ & $0.48 \pm 0.06$ \\
\hline HCT116 $\left(p 53^{-} /^{-}\right)$ & $44.20 \pm 3.21$ & $>165.29$ & $>153.85$ & $112.27 \pm 8.49$ & $>91.74$ & $>85.47$ & $1.78 \pm 0.08$ \\
\hline Degree of resistance & 2.55 & $>3.54$ & $>6.15$ & 1.49 & nd & $>2.26$ & 3.73 \\
\hline U87MG & $16.16 \pm 1.09$ & $74.44 \pm 4.75$ & $106.00 \pm 6.74$ & $61.42 \pm 3.39$ & $29.70 \pm 1.77$ & $35.50 \pm 3.28$ & $0.26 \pm 0.03$ \\
\hline U87MG. $\triangle E G F R$ & $14.69 \pm 1.55$ & $44.98 \pm 5.22$ & $30.37 \pm 2.91$ & $59.04 \pm 6.01$ & $12.72 \pm 0.75$ & $30.61 \pm 3.14$ & $0.98 \pm 0.07$ \\
\hline Degree of resistance & 0.91 & 0.60 & 0.29 & 0.96 & 0.43 & 0.86 & 3.79 \\
\hline HepG2 & $21.68 \pm 3.18$ & $44.21 \pm 2.65$ & $32.40 \pm 3.72$ & $64.73 \pm 5.77$ & $25.19 \pm 1.69$ & $31.29 \pm 1.19$ & $4.56 \pm 0.48$ \\
\hline AML12 & $47.34 \pm 0.81$ & $>165.29$ & $45.35 \pm 3.52$ & $150.02 \pm 7.03$ & $20.89 \pm 1.17$ & $>85.47$ & $52.90 \pm 4.09$ \\
\hline Selectivity index** & 2.18 & $>3.74$ & 1.40 & 2.32 & 0.83 & $>2.73$ & 11.59 \\
\hline
\end{tabular}

$\left({ }^{*}\right)$ : the degree of resistance was determined as the ratio of the $\mathrm{IC}_{50}$ value in the resistant divided by the $\mathrm{IC}_{50}$ in the sensitive cell line; CEM/ADR5000, MDAMB-231-BCRP, HCT116 $\left(p 53^{-} /^{-}\right)$, and U87MG. $\triangle E G F R$ were used as the corresponding resistant counterparts for CCRF-CEM, MDA-MB-231-pcDNA, HCT116 $\left(p 53^{+/+}\right)$, and U87MG, respectively; $\left({ }^{* *}\right)$ : the selectivity index was determined as the ratio of the $\mathrm{IC}_{50}$ value in the normal AML12 hepatocytes divided by the $\mathrm{IC}_{50}$ in HepG2 hepatocarcinoma cells; in bold: significant cytotoxic effect $[7,39,40]$, the cytotoxicity of compound $\mathbf{6}$ (betulenic acid) on these cell lines was previous reported [41], and this compound was no more tested in this study, no $\mathrm{IC}_{50}$ value was recorded at up to $100 \mu \mathrm{M}$ with compound 2; nd: not determined; 1: trichadonic acid; 3: 2-hydroxy-5-methoxyxanthone; 4: 1,3,6,7-tetrahydroxyxanthone or norathyriol; 5: 1,3,5,6-tetrahydroxyxanthone; 7: $3^{\prime}$ -

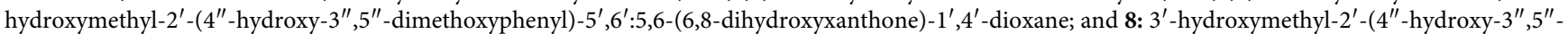
dimethoxyphenyl)-5', $6^{\prime}: 5,6$-(xanthone)-1', $4^{\prime}$-dioxane.
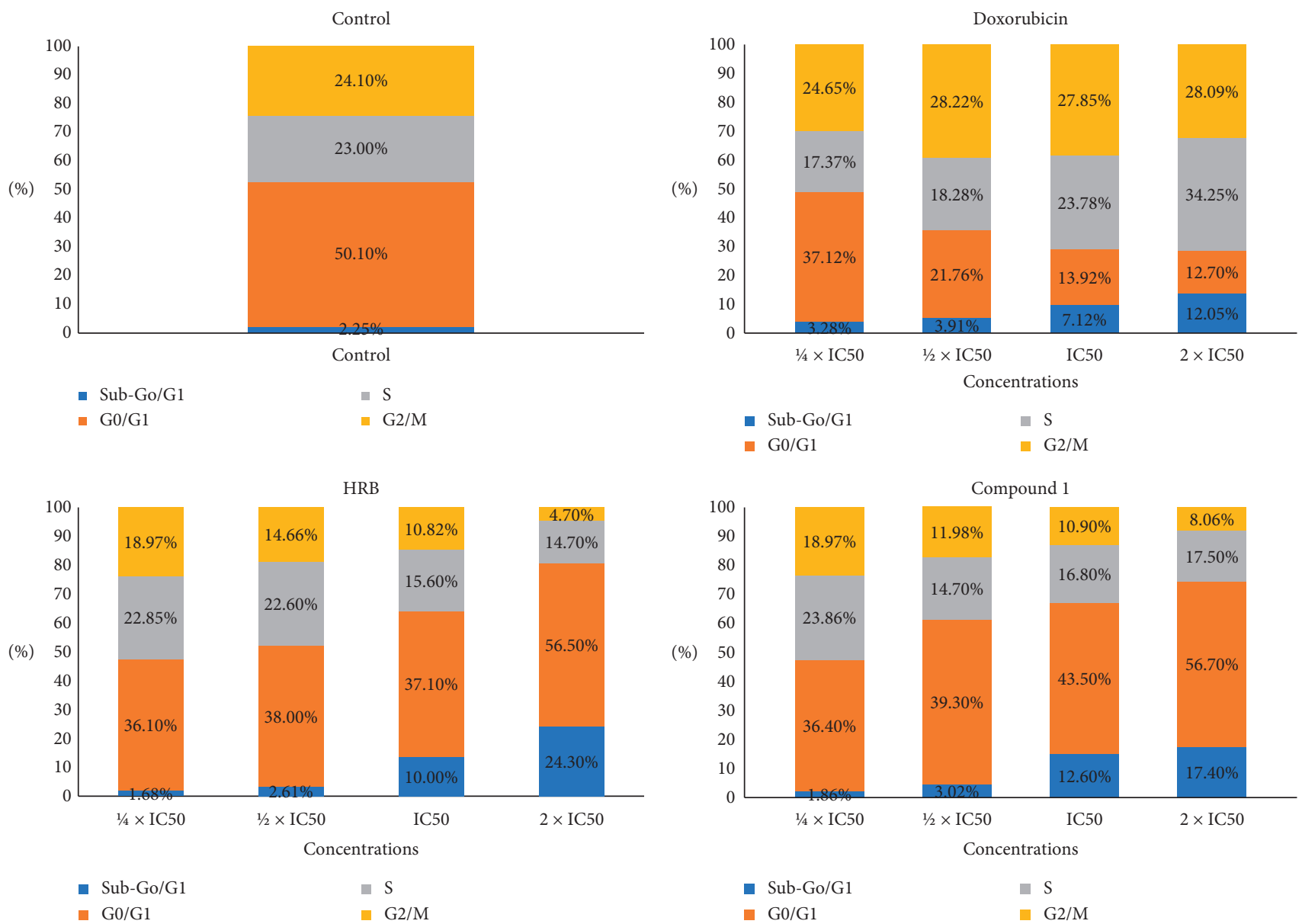

FIgURE 2: Distribution of the CCRF-CEM cells cycle after treatment with the crude extract (HRB), compound 1 (trichadonic acid), and doxorubicin. $\mathrm{IC}_{50}$ values were $14.44 \mu \mathrm{M}$ for trichadonic acid and $0.02 \mu \mathrm{M}$ for doxorubicin. 


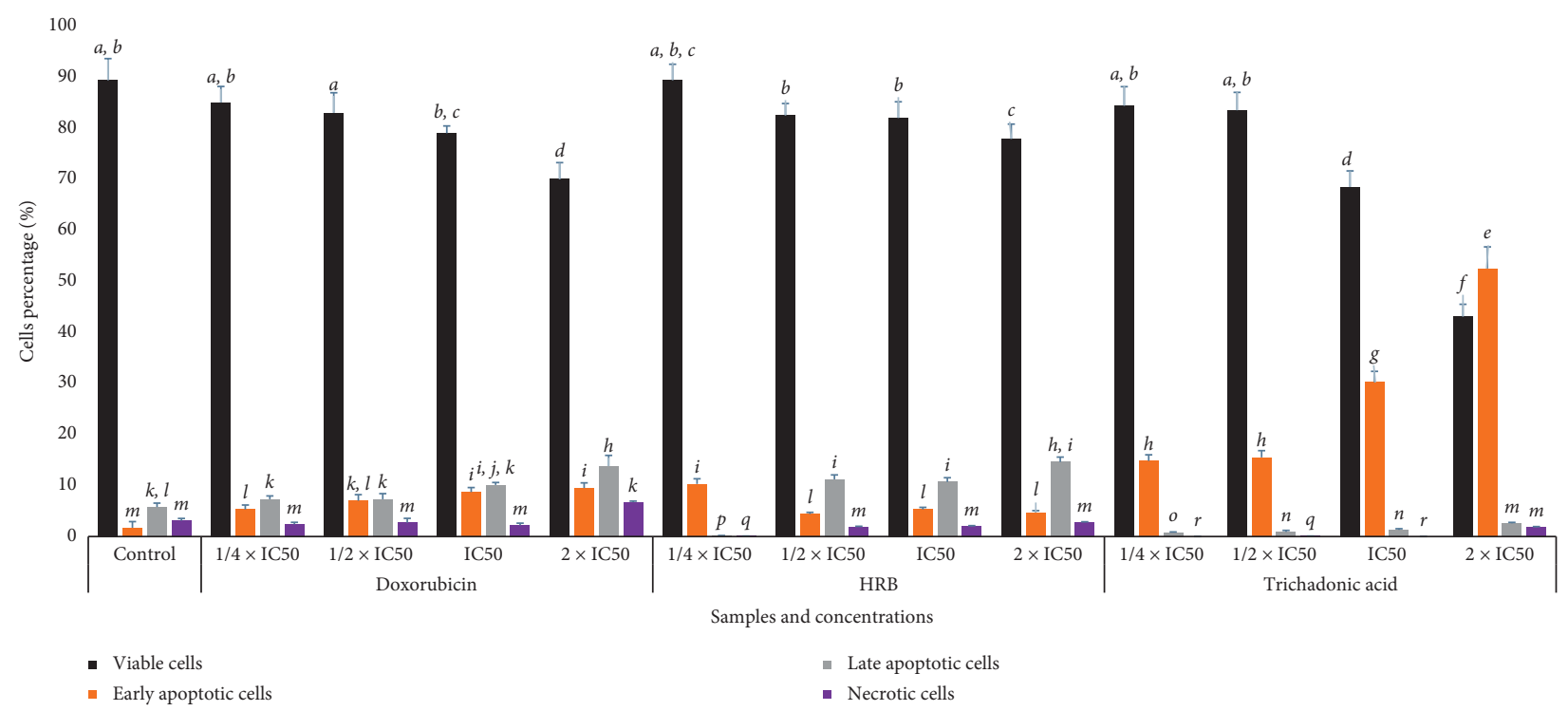

FIgURE 3: Apoptosis induced by the crude extract (HRB), trichadonic acid, and doxorubicin after $24 \mathrm{~h}$ on CCRF-CEM leukemia cells as determined by annexin V/PI assay. Apoptosis was assessed by flow cytometry after annexin V-PI double staining. IC $\mathrm{C}_{50} \mathrm{values}$ were $13.71 \mu \mathrm{g} /$ $\mathrm{mL}$ for $\mathrm{HRB}, 14.44 \mu \mathrm{M}$ for trichadonic acid, and $0.02 \mu \mathrm{M}$ for doxorubicin. Mean values $\pm \mathrm{SD}$ of three independent experiments is shown. Data with different superscript letters are significantly different $(p<0.05)$.

3.4. Activation of Caspases and Production of ROS. In the presence of the tested samples, the activity of caspases in CCRF-CEM cells increased by 1.18-fold, 1.45-fold, and 1.35fold for HRB and by 2.52-fold, 2.62-fold, and 2.23-fold for trichadonic acid (1), respectively, for caspases $3 / 7,8$, and 9 (Figure 4).

The production of reactive oxygen species (ROS) in CCRF-CEM cells treated with $\mathrm{HRB}$, triterpenoid $1, \mathrm{H}_{2} \mathrm{O}_{2}$ (positive control), or DMSO was analyzed, and the results are depicted in Figure 5. The crude extract HRB significantly $(p<0.05)$ induced increase of ROS production in a range of $8.98 \%\left(1 / 4 \times \mathrm{IC}_{50}\right)$ to $71.92 \%\left(2 \times \mathrm{IC}_{50}\right)$; compound 1 also significantly $(p<0.05)$ induced increase of ROS production in a range of $12.35 \%(7.22 \mu \mathrm{M})$ to $68.12 \%(57.76 \mu \mathrm{M})$. The reference compound, $\mathrm{H}_{2} \mathrm{O}_{2}$, increased the ROS levels to $94.30 \%$ at $50 \mu \mathrm{M}$, while ROS production in nontreated cells was $0.6 \%$.

\section{Discussion}

Taking into account the rapid development of resistance by cancer cell lines, the use of MDR phenotypes when screening phytochemicals is an interesting approach. Collateral or normal sensitivity (D.R. below or equal to 1) of MDR cells to phytochemicals combined to their good cytotoxicity could be better criteria to select substances for clinical studies. In the present work, four MDR cells lines, CEM/ADR5000 cells, MDA-MB-231-BCRP cells, HCT116 $\left(p 53^{-} /^{-}\right)$cells, and U87.MG $\triangle E G F R$ cells, were used, and their susceptibilities to isolated phytochemicals were compared with those of their parental sensitive counterparts, CCRF-CEM cells, MDAMB-231 cells, HCT116 $\left(p 53^{+/+}\right)$cells, and U87.MG cells, respectively (Tables 1 and 2 ). Interestingly, collateral sensitivity of CEM/ADR5000 cells, BCRP-expressing MDAMB-231 cells, and HCT116 $\left(\mathrm{p} 53^{-/-}\right)$cells to HRB was achieved, as well as the hypersensitivity of all resistant cell lines to fraction $\mathrm{HRBa} 4$ and $\mathrm{HRBb}$ compared to their sensitive parental cell lines (Table 1). Collateral sensitivity of BCRP-expressing MDA-MB-231 cells and U87MG. $\triangle E$ EFR cells to phytochemicals $\mathbf{1}, \mathbf{3 - 5}$, and 8 was observed, suggesting that they might be useful to fight drug resistance in breast cancer and glioblastoma (Table 2). This clearly indicates that these botanicals and phytochemicals can be exploited in the fight against recalcitrant cancers. The $\mathrm{IC}_{50}$ values below $20 \mu \mathrm{g} / \mathrm{mL}$ or below $10 \mu \mathrm{M}$ after incubation between 48 and $72 \mathrm{~h}$ have been set for promising cytotoxic botanicals and phytochemicals, respectively [39, 40]. Importantly, IC $_{50}$ values below $20 \mu \mathrm{g} / \mathrm{mL}$ were obtained with $\mathrm{HRB}$ against $8 / 9$ tested cancer cells lines, $\mathrm{HRBa} 2$ and $\mathrm{HRBa} 4$ against 7/9 cancer cell lines, $\mathrm{HRBa}$ against $4 / 9$ cancer cell lines, and $\mathrm{HRBa} 3$ against $3 / 9$ cell lines (Table 1 ). It can, therefore, be confirmed that these botanicals are interesting cytotoxic agents. However, $\mathrm{IC}_{50}$ values below the established threshold were not achieved with phytochemicals, though terpenoid $\mathbf{1}$ and xanthone $\mathbf{5}$ had cytotoxic effects towards the 9 tested cancer cell lines. However, their good selectivity indexes still suggest that they can still be good candidates to tackle cancers, especially when drug resistance is observed. To the best of our knowledge, the cytotoxicity of the crude extract and compounds $1,2,3,7$, and $\mathbf{8}$ on the studied cell lines is being reported, herein, for the first time. Betulinic acid (6) is a well-known cytotoxic compound and has previously been found active towards the cancer cell lines tested in the present work, with $\mathrm{IC}_{50}$ values ranging from $7.65 \mu \mathrm{M}$ (in CEM-ADR5000 cells) to $44.17 \mu \mathrm{M}$ (in HepG2 cells) [41]. Although it was not further tested, herein, compound 6 can be ranked amongst the best active principles of Hypericum roeperianum. Also, the cytotoxicity of norathyriol (4) in JB6 P+ mouse skin epidermal cells was reported [42]. 1,3,5,6-Tetrahydroxyxanthone (5) had low 

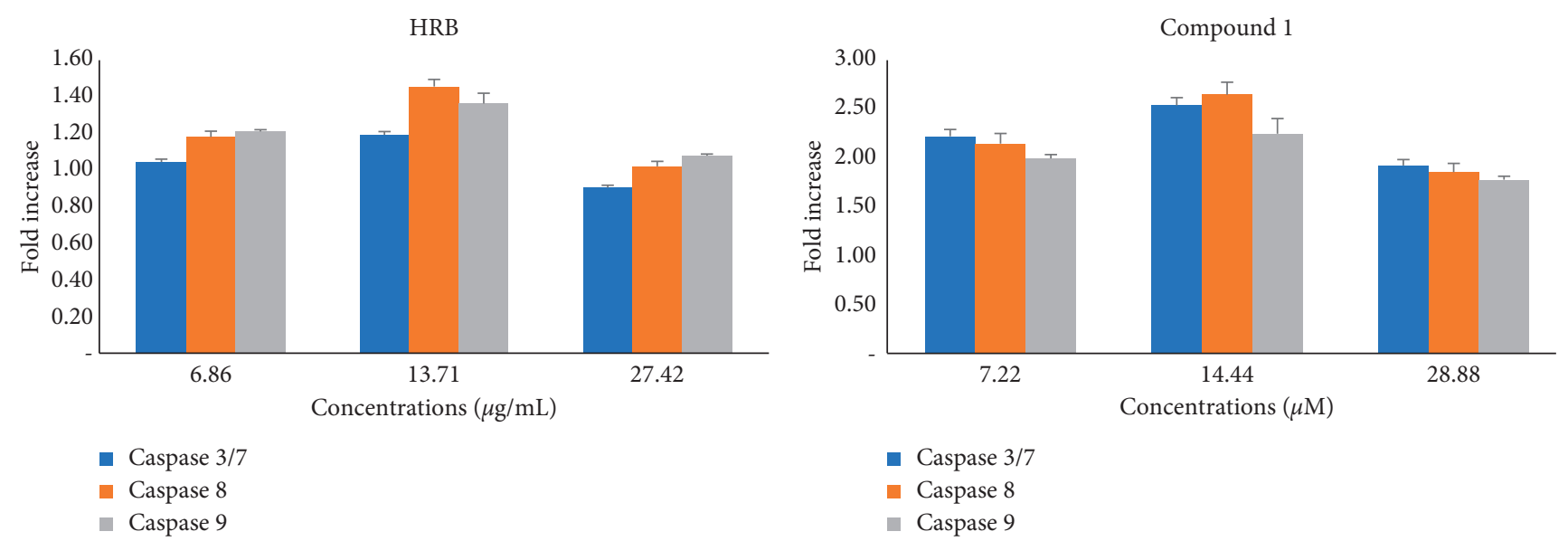

FIGURE 4: Caspases activities in CCRF-CEM cells treated with the crude extract (HRB) and trichadonic acid for $6 \mathrm{~h} \mathrm{IC} \mathrm{C}_{50}$ of $\mathrm{HRB}: 13.71 \mu \mathrm{g} / \mathrm{mL}$ and trichadonic acid: $14.44 \mu \mathrm{M}$; (A) caspase activity is expressed as percentage (\%) compared to untreated cells. Mean \pm SD of three independent experiments is shown.

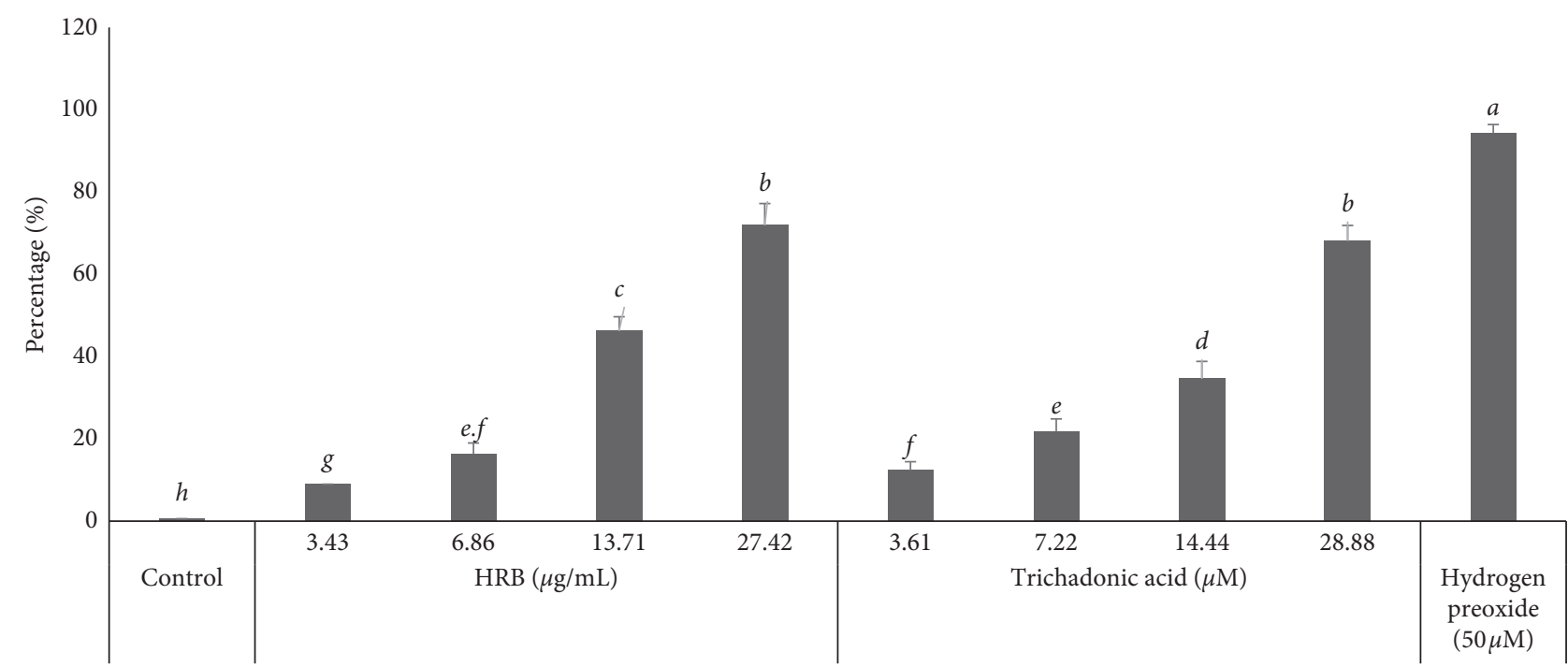

Figure 5: Effects of the crude extract (HRB), trichadonic acid, and hydrogen peroxide $\left(\mathrm{H}_{2} \mathrm{O}_{2}\right)$ on the production of reactive oxygen species (ROS) in CCRF-CEM cells treated for $24 \mathrm{~h}$. Mean \pm SD of three independent experiments is shown. Data with different superscript letters are significantly different $(p<0.05)$.

cytotoxic effects against K562 leukemia cells with $12.98 \mu \mathrm{g} /$ $\mathrm{mL}(49.92 \mu \mathrm{M})$ [43].

Apoptosis is a programmed cell death and is also the most investigated mechanism of action of antiproliferative drugs. In this study, it was found that both HRB and compound $\mathbf{1}$ induced apoptosis in CCRF-CEM cells with cell cycle arrest in the Go/G1 phase (Figures 2 and 3). Modulation of caspases activities is one of the events observed in the apoptotic process in cancer cell lines [44], making these enzymes a target for cytotoxic drug discovery [8, 45]. However, no significant increase in the activity of initiator caspases (caspases 8 and 9) or in that of the activator caspases (caspase 3/7) was observed (Figure 4). Phytochemical 1 induced 2.52-fold, 2.62-fold, and 2.23-fold increase of the activity of caspases $3 / 7,8$, and 9 , respectively (Figure 4), suggesting that this molecule is a caspase modulator. Botanical HRB and compound $\mathbf{1}$ were also shown to induce increase of ROS by up to $71.92 \%$ and $68.12 \%$, respectively $\left(2 \times \mathrm{IC}_{50}\right.$; Figure 5$)$; this is an indication that one of the modes of action of this triterpenoid also includes the enhancement of ROS production in cancer cells.

Regarding the structure-activity relationship, it appears that pentacyclic triterpene $\mathbf{1}$ is different from $\mathbf{2}$ by the presence of the carboxyl group (-COOH) in C-13 (Figure 1); the presence of this $-\mathrm{COOH}$ group significantly enhanced the cytotoxic activity of triterpene $\mathbf{1}$, with $\mathrm{IC}_{50}$ values ranging from $14.44 \mu \mathrm{M}$ to $44.20 \mu \mathrm{M}$ in cancer cells tested whilst no $\mathrm{IC}_{50}$ value at up to $100 \mu \mathrm{M}$ was recorded with triterpene 2 (Table 1). Betulic acid, another pentacyclic triterpene with-COOH in C-17, previously displayed good cytotoxicity against all cancer cell lines tested in this work [41], illustrating the importance of the carboxyl function in the cytotoxicity of pentacyclic triterpenes. Concerning xanthones, though $\mathbf{5}$ was active in all tested cancer cell lines, 
3-5 displayed moderate activities (Table 1). It was previously shown that additional hetrocycle in xanthone combined to prenylation improved the cytotoxicity of xanthones, with cudraxanthone I (additional hetrocycle combined to -C-8prenylation) displaying significant cytotoxic effects $\left(\mathrm{IC}_{50}\right.$ value below $10 \mu \mathrm{M}$ ) against all cancer cell lines tested in the present study [46]. This observation is also confirmed with another prenylated xanthone bearing additional herocycle, xanthone V1 [47]. The difference between the two xanthonolignoids $\mathbf{7}$ and $\mathbf{8}$ is the presence of two hydroxyl $(-\mathrm{OH})$ groups in C-6 and C-7 (Compound 8) (Figure 1). This difference seems to influence the selectivity, as compound $\mathbf{8}$ was active against HCT116 $\left(p 53^{+/+}\right)$cells, with an $\mathrm{IC}_{50}$ value of $37.79 \mu \mathrm{M}$ compared to the $\mathrm{IC}_{50}$ value above $91.74 \mu \mathrm{M}$ obtained for compound 7 (against the same cell line (Table 1).

\section{Conclusions}

The present work demonstrated that Hypericum roeperianum is a source of cytotoxic compounds. Triterpenoids such as trichadonic acid (1) and betulinic acid (6), xonthones (2-hydroxy-5-methoxyxanthone (3), norathyriol (4), and 1,3,5,6-tetrahydroxyxanthone (5)), and xantholignoids ( $3^{\prime}$-hydroxymethyl- $2^{\prime}-\left(4^{\prime \prime}\right.$-hydroxy$3^{\prime \prime}, 5^{\prime \prime}$-dimethoxyphenyl)-5',6':5,6-(6,8-dihydroxyxanth one)- $1^{\prime}, 4^{\prime}$-dioxane (7) and $3^{\prime}$-hydroxymethyl- $2^{\prime}-\left(4^{\prime \prime}\right.$ hydroxy- $3^{\prime \prime}, 5^{\prime \prime}$-dimethoxyphenyl)- $5^{\prime}, 6^{\prime}: 5,6$-(xanthone)-

$1^{\prime}, 4^{\prime}$-dioxane $\left.(8)\right)$ are amongst the active constituents of this plant. Trichadonic acid (1) induced apoptosis in CCRF-CEM leukemia cells, through caspases activation and enhancement of ROS production. The crude extract, $\mathrm{HRB}$, also induced apoptosis in CCRF-CEM cells, mediated by enhancement of ROS production. These compounds can potentially be useful in the fight against recalcitrant cancers.

\section{Abbreviations}

1: Trichadonic acid

2: Fridelan-3-one

3: 2-Hydroxy-5-methoxyxanthone

4: 1,3,6,7-Tetrahydroxyxanthone or norathyriol

5: 1,3,5,6-Tetrahydroxyxanthone

6: Betulenic acid

7: $3^{\prime}$-Hydroxymethyl-2' - $\left(4^{\prime \prime}\right.$-hydroxy- $3^{\prime \prime}, 5^{\prime \prime}$ dimethoxyphenyl)-5', $6^{\prime}: 5,6$-(6,8-dihydroxyxanthone)$1^{\prime}, 4^{\prime}$-dioxane

8: $3^{\prime}$-Hydroxymethyl-2' $-\left(4^{\prime \prime}\right.$-hydroxy- $3^{\prime \prime}, 5^{\prime \prime}$ dimethoxyphenyl)- $5^{\prime}, 6^{\prime}: 5,6$-(xanthone)- $1^{\prime}, 4^{\prime}$-dioxane; $\mathrm{ABC}, \mathrm{ATP}$-binding cassette; BCRP, breast cancer resistance protein; DMSO, dimethylsulfoxide; D.R., resistance; EGFR, epidermal growth factor receptor; FITC, flourescein isothiocynate; $\mathrm{H}_{2} \mathrm{O}_{2}$, hydrogen peroxide; H2DCFH-DA, $2^{\prime}, 7^{\prime}$ -

dichlorodihydrofluoresceine diacetate; HRB, methanol extract of the bark of Hypericum roeperianum; HRBa, portion obtained by exhaustion of HRB with ethyl acetate; HRBa1-5, fractions from HRBa; HRBb, Residual fraction obtained after exhaustion of HRB with ethyl acetate; $\mathrm{IC}_{50}, 50 \%$ inhibitory concentration; MDR, multidrug resistance; PBS, phosphate buffer saline; P-gp, $\mathrm{P}$-glycoprotein; PI, propidium iodide; and ROS, reactive oxygen species

\section{Data Availability}

All data generated or analyzed during this study are included in this published article and its supplementary information files.

\section{Conflicts of Interest}

The authors declare that they have no conflicts of interest.

\section{Authors' Contributions}

SBT, FD, M-GGF, ATM, and VK carried out the experiments; IC recorded NMR data; FD, GTMB, and JDSM elucidated the chemical structures; ATM and VK wrote the manuscript; and all authors read and approved the final manuscript.

\section{Acknowledgments}

The authors wish to autograph this work in memory for Pierre Tane (Professor) who was the supervisor of the chemical part of this work. The authors are thankful to Prof. Dr. Thomas Efferth for providing facilities for biological studies. SBT and VK are grateful to the Alexander von Humboldt Foundation for the 6 months' further research stay fellowship in Mainz. The authors acknowledge the Scientific Research Projects Commission of Anadolu University, Eskisehir, Turkey, for the grant 1306F110 to IC.

\section{Supplementary Materials}

Additional File: S1: NMR spectra and main chemical shifts of compounds: NMR spectra and main chemical shifts of the isolated compounds; S2: diagrams of annexin V/PI staining of CCRF-CEM with HRB and trichadonic acid. (Supplementary Materials)

\section{References}

[1] IARC, Latest Global Cancer Data: Cancer Burden Rises to 18.1 Million New Cases and 9.6 Million Cancer Deaths in 2018, International Agency for Research on Cancer, Lyon, France, 2020, https://www.who.int/cancer/PRGlobocanFinal.pdf.

[2] D. A. Vorobiof and R. Abratt, "The cancer burden in Africa," South African Medical Journal=Suid-Afrikaanse Tydskrif Vir Geneeskunde, vol. 97, no. 10, pp. 937-939, 2007.

[3] C. Fitzmaurice, C. Fitzmaurice, D. Dicker et al., "The global burden of cancer 2013," JAMA Oncology, vol. 1, no. 4, pp. 505-527, 2015.

[4] N. R. Farnsworth and D. D. Soejarto, "Global importance of medicinal plants," in Conservation of Medicinal Plants, pp. 25-51, Cambridge University Press, Cambridge, UK, 1991.

[5] R. F. Ludueña, "Immunsystem," Klinische Biochemie, vol. 178, pp. 207-230, 1997. 
[6] N. P. Gullett, A. R. M. Ruhul Amin, S. Bayraktar et al., "Cancer prevention with natural compounds," Seminars in Oncology, vol. 37, no. 3, pp. 258-281, 2010.

[7] V. Kuete and T. Efferth, "African flora has the potential to fight multidrug resistance of cancer," BioMed Research International, vol. 2015, Article ID 914813, 2015.

[8] A. T. Mbaveng, V. Kuete, and T. Efferth, "Potential of Central, Eastern and Western Africa medicinal plants for cancer therapy: spotlight on resistant cells and molecular targets," Frontiers in Pharmacology, vol. 8, p. 343, 2017.

[9] M.-E. F. Hegazy, A. R. Hamed, A. M. El-Halawany et al., "Cytotoxicity of abietane diterpenoids from Salvia multicaulis towards multidrug-resistant cancer cells," Fitoterapia, vol. 130, pp. 54-60, 2018.

[10] A. T. Mbaveng, G. W. Fotso, D. Ngnintedo et al., "Cytotoxicity of epunctanone and four other phytochemicals isolated from the medicinal plants Garcinia epunctata and Ptycholobium contortum towards multi-factorial drug resistant cancer cells," Phytomedicine, vol. 48, pp. 112-119, 2018.

[11] A. T. Mbaveng, B. L. Ndontsa, V. Kuete et al., "A naturally occuring triterpene saponin ardisiacrispin B displayed cytotoxic effects in multi-factorial drug resistant cancer cells via ferroptotic and apoptotic cell death," Phytomedicine, vol. 43, pp. 78-85, 2018.

[12] V. Kuete, A. T. Mbaveng, L. P. Sandjo, M. Zeino, and T. Efferth, "Cytotoxicity and mode of action of a naturally occurring naphthoquinone, 2-acetyl-7-methoxynaphtho[2,3b]furan-4,9-quinone towards multi-factorial drug-resistant cancer cells," Phytomedicine, vol. 33, pp. 62-68, 2017.

[13] V. Kuete, L. P. Sandjo, D. E. Djeussi et al., "Cytotoxic flavonoids and isoflavonoids from Erythrina sigmoidea towards multi-factorial drug resistant cancer cells," Investigational New Drugs, vol. 32, no. 6, pp. 1053-1062, 2014.

[14] F. A. Adem, V. Kuete, A. T. Mbaveng et al., "Cytotoxic benzylbenzofuran derivatives from Dorstenia kameruniana," Fitoterapia, vol. 128, pp. 26-30, 2018.

[15] F. A. Adem, A. T. Mbaveng, and V. Kuete, "Cytotoxicity of isoflavones and biflavonoids from Ormocarpum kirkii towards multi-factorial drug resistant cancer," Phytomedicine, vol. 58, Article ID 152853, 2019.

[16] V. Kuete, H. Fouotsa, A. T. Mbaveng, B. Wiench, A. E. Nkengfack, and T. Efferth, "Cytotoxicity of a naturally occurring furoquinoline alkaloid and four acridone alkaloids towards multi-factorial drug-resistant cancer cells," Phytomedicine, vol. 22, no. 10, pp. 946-951, 2015.

[17] V. Kuete, L. P. Sandjo, A. T. Mbaveng, M. Zeino, and T. Efferth, "Cytotoxicity of compounds from Xylopia aethiopica towards multi-factorial drug-resistant cancer cells," Phytomedicine, vol. 22, no. 14, pp. 1247-1254, 2015.

[18] A. T. Mbaveng, G. T. M. Bitchagno, V. Kuete, P. Tane, and T. Efferth, "Cytotoxicity of ungeremine towards multi-factorial drug resistant cancer cells and induction of apoptosis, ferroptosis, necroptosis and autophagy," Phytomedicine, vol. 60, Article ID 152832, 2019.

[19] M. Iwu, Handbook of African Medicinal Plants, CRC Press, Boca Raton, FL, USA, 1993.

[20] H. M. Burkill, The Useful Plants of West Tropical Africa, Vol. 2, Royal Botanic Gardens, Kew, UK, 1985.

[21] M. J. Moshi, C. J. van den Beukel, and O. J. Hamza, "Brine shrimp toxicity evaluation of some Tanzanian plants used traditionally for the treatment of fungal infections," African Journal of Traditional Complementary and Alternative Medicine, vol. 4, no. 2, pp. 219-225, 2007.
[22] F. Damen, O. M. F. Demgne, G. T. M. Bitchagno et al., "A new polyketide from the bark of Hypericum roeperianum Schimp." Natural Product Research, pp. 1-7, 2019.

[23] G. Rath, O. Potterat, S. Mavi, and K. Hostettmann, "Xanthones from Hypericum roeperanum," Phytochemistry, vol. 43, no. 2, pp. 513-520, 1996.

[24] A. Kimmig, V. Gekeler, M. Neumann et al., "Susceptibility of multidrug-resistant human leukemia cell lines to human interleukin 2-activated killer cells," Cancer Research, vol. 50, no. 21, pp. 6793-6799, 1990.

[25] T. Efferth, A. Sauerbrey, A. Olbrich et al., "Molecular modes of action of artesunate in tumor cell lines," Molecular Pharmacology, vol. 64, no. 2, pp. 382-394, 2003.

[26] J.-P. Gillet, T. Efferth, D. Steinbach et al., "Microarray-based detection of multidrug resistance in human tumor cells by expression profiling of ATP-binding cassette transporter genes," Cancer Research, vol. 64, no. 24, pp. 8987-8993, 2004.

[27] L. A. Doyle, W. Yang, L. V. Abruzzo et al., "A multidrug resistance transporter from human MCF-7 breast cancer cells," Proceedings of the National Academy of Sciences, vol. 95, no. 26, pp. 15665-15670, 1998.

[28] J. O'Brien, I. Wilson, T. Orton, and F. Pognan, "Investigation of the Alamar Blue (resazurin) fluorescent dye for the assessment of mammalian cell cytotoxicity," European Journal of Biochemistry, vol. 267, no. 17, pp. 5421-5426, 2000.

[29] V. Kuete, A. H. L. Nkuete, A. T. Mbaveng et al., "Cytotoxicity and modes of action of $4^{\prime}$-hydroxy-2 $2^{\prime}, 6^{\prime}$-dimethoxychalcone and other flavonoids toward drug-sensitive and multidrugresistant cancer cell lines," Phytomedicine, vol. 21, no. 12, pp. 1651-1657, 2014.

[30] D. A. Bass, J. W. Parce, L. R. Dechatelet, P. Szejda, M. C. Seeds, and M. Thomas, "Flow cytometric studies of oxidative product formation by neutrophils: a graded response to membrane stimulation," Journal of Immunology (Baltimore, Md.:1950), vol. 130, no. 4, pp. 1910-1917, 1983.

[31] A. Cossarizza, R. Ferraresi, L. Troiano et al., "Simultaneous analysis of reactive oxygen species and reduced glutathione content in living cells by polychromatic flow cytometry," Nature Protocols, vol. 4, no. 12, pp. 1790-1797, 2009.

[32] V. Kuete, S. B. Tankeo, M. E. M. Saeed, B. Wiench, P. Tane, and T. Efferth, "Cytotoxicity and modes of action of five Cameroonian medicinal plants against multi-factorial drug resistance of tumor cells," Journal of Ethnopharmacology, vol. 153, no. 1, pp. 207-219, 2014.

[33] S. B. Mahato and A. P. Kundu, "13C NMR spectra of pentacyclic triterpenoids-A compilation and some salient features," Phytochemistry, vol. 37, no. 6, pp. 1517-1575, 1994.

[34] M. L. Cardona, J. R. Pedro, E. Seoane, and R. Vidal, "Xanthone constituents of Hypericum canariensis," Journal of National Products, vol. 48, no. 3, pp. 467-469, 2004.

[35] C. Çirak, "Hypericin in Hypericum lydium boiss. growing in Turkey," Biochemical Systematics and Ecology, vol. 34, no. 12, pp. 897-899, 2006.

[36] M.-J. Don, Y.-J. Huang, R.-L. Huang, and Y.-L. Lin, "New phenolic principles from Hypericum sampsonii," Chemical \& Pharmaceutical Bulletin, vol. 52, no. 7, pp. 866-869, 2004.

[37] M. Abou-shoer, A.-A. Habib, C.-J. Chang, and J. M. Cassady, "Seven xanthonolignoids from Psorospermum febrifugum," Phytochemistry, vol. 28, no. 9, pp. 2483-2487, 1989.

[38] M. L. Cardona, M. I. Fernández, J. R. Pedro, E. Seoane, and R. Vidal, "Additional new xanthones and xanthonolignoids from Hypericum canariensis," Journal of Natural Products, vol. 49, no. 1, pp. 95-100, 1986. 
[39] J. Boik, Natural Compounds in Cancer Therapy, Oregon Medical Press, Princeton, MN, USA, 2001.

[40] G. Brahemi, F. R. Kona, A. Fiasella et al., "Exploring the structural requirements for inhibition of the ubiquitin E3 ligase breast cancer associated protein 2 (BCA2) as a treatment for breast cancer," Journal of Medicinal Chemistry, vol. 53 , no. 7, pp. 2757-2765, 2010.

[41] A. T. Mbaveng, F. Damen, and J. D. Simo Mpetga, "Cytotoxicity of crude extract and isolated constituents of the Dichrostachys cinerea bark towards multifactorial drug-resistant cancer cells," Evidence- Based Complementary and Alternative Medicine, vol. 2019, Article ID 8450158, 2019.

[42] J. Li, M. Malakhova, M. Mottamal et al., "Norathyriol suppresses skin cancers induced by solar ultraviolet radiation by targeting ERK kinases," Cancer Research, vol. 72, no. 1, pp. 260-270, 2012.

[43] N. H. Zamakshshari, G. C. L. Ee, I. S. Ismail, Z. Ibrahim, and S. H. Mah, "Cytotoxic xanthones isolated from Calophyllum depressinervosum and Calophyllum buxifolium with antioxidant and cytotoxic activities," Food and Chemical Toxicology, vol. 133, Article ID 110800, 2019.

[44] Y. Fuchs and H. Steller, "Programmed cell death in animal development and disease," Cell, vol. 147, no. 4, pp. 742-758, 2011.

[45] B. Howley and H. O. Fearnhead, "Caspases as therapeutic targets," Journal of Cellular and Molecular Medicine, vol. 12, no. 5A, pp. 1502-1516, 2008.

[46] V. Kuete, L. P. Sandjo, J. L. N. Ouete, H. Fouotsa, B. Wiench, and T. Efferth, "Cytotoxicity and modes of action of three naturally occurring xanthones (8-hydroxycudraxanthone G, morusignin I and cudraxanthone I) against sensitive and multidrug-resistant cancer cell lines," Phytomedicine, vol. 21, no. 3, pp. 315-322, 2014.

[47] V. Kuete, H. K. Wabo, and K. O. Eyong, “Anticancer activities of six selected natural compounds of some Cameroonian medicinal plants," PLoS One, vol. 6, no. 8, Article ID e21762, 2011. 